\title{
CLINICAL OUTCOME OF PATIENTS WITH DIFFUSE AXONAL INJURY RECEIVING ADRENOCORTICOTROPIN ANALOGUE AT DR. SOETOMO HOSPITAL
}

\author{
Joni Wahyuhadi, Pandu Wicaksono, Hari Basuki Notobroto \\ Department of Neurosurgery, Faculty of Medicine, Universitas Airlangga, Dr. Soetomo Hospital, Surabaya, Indonesia
}

\section{ABSTRACT}

\begin{abstract}
Brain traumatic injury (BTI) is one of the causes of death and disability worldwide that affects people regardless of sex, age, income and social status, race, or nationality. In patients with brain traumatic injury, one of the problems that occurs is Diffuse Axonal Injury (DAI) that can produce a direct clinical effect, leading to coma and death. Adrenocorticotropin analogues (ACTH) is one of neuroprotective therapy in brain injury. The aim of this study was to analyze the effect of ACTH analogue on the clinical output (Glasgow Outcome Score/GOS and Bartle Index) in patients with DAI at hospital discharge, 3 months and 6 months post-treatment. This study revealed that ACTH analogue administration resulted in higher GOS and Barthel Index scores than that in control. Further study will required with other variables, such as cognitive and motor examination, and some biomarkers can also be examined serially.
\end{abstract}

Keywords: Diffuse Axonal Injury; adrenocorticotropin; Glasgow Outcome Score; Barthel Index

\section{ABSTRAK}

Cedera traumatik otak adalah salah satu penyebab kematian dan kecacatan di seluruh dunia yang dapat menyerang siapa saja tanpa memandang jenis kelamin, usia, pendapatan dan status sosial, ras, atau kebangsaan. Pada pasien dengan cedera otak traumatis, salah satu masalah yang terjadi adalah Diffuse Axonal Injury (DAI) yang dapat menghasilkan efek klinis yang langsung mengarah ke koma dan kematian. Analog adrenokortikotropin (ACTH) adalah salah satu terapi neuroprotektif pada cedera otak. Tujuan dari penelitian ini adalah untuk menganalisis pengaruh analog ACTH pada output klinis (Glasgow Outcome Score/GOS dan Indeks Bartle) pada pasien dengan DAI di rumah sakit, 3 bulan dan 6 bulan pasca perawatan. Studi ini mengungkapkan bahwa pemberian analog ACTH menghasilkan skor GOS dan Indeks Barthel yang lebih tinggi daripada kontrol. Diperlukan penelitian lebih lanjut dengan variabel lain, seperti pemeriksaan kognitif dan motorik dan beberapa biomarker juga dapat diteliti secara serial.

Kata kunci: Diffuse Axonal Injury; adrenocorticotropin; Glasgow Outcome Score; Indeks Barthel

Correspondence: Joni Wahyuhadi, Neurosurgery Department, Faculty of Medicine, Universitas Airlangga, Dr. Soetomo Hospital, Surabaya, Indonesia. E-mail: joni.wahyuhadi@gmail.com

pISSN:2355-8393 • eISSN: 2599-056x • doi: http://dx.doi.org/10.20473/fmi.v54i3.10019

$\bullet$ Fol Med Indones. 2018;54:222-227 • Received 8 Feb $2018 \bullet$ Accepted 16 Aug 2018

- Open access under CC-BY-NC-SA license • Available at https://e-journal.unair.ac.id/FMI/

\section{INTRODUCTION}

Traumatic brain injury (TBI) is one of the causes of death and disability worldwide that affects people regardless of sex, age, income and social status, race, or nationality (Jallo \& Loftus 2009). The study of TBI in dr. Soetomo Hospital for 12 years (2002-2013) showed total patients wof 17.254 , including the severe TBI in 2.749 patients (16\%). The average case of TBI was 1 . 438 cases per year, and the average case of severe TBI was 230, including diffuse Axonal Injury (DAI) cases per year. Total mortality rate was ranging from $5.11 \%$ to $13.4 \%$. Based on the severity, the mortality of severe traumatic brain injury patients is still high, ranging from
$13.8 \%$ to $66.2 \%$, the average was $30.6 \%$ with a decreasing trend (Wahyuhadi et al 2014).

Globally around the world, it is estimated that there are more than 100,000 patients with varying degrees of disability due to brain injury each year. One study reported that the mortality rate reached $23.9 \%$ in patients with diffuse injury and $40.4 \%$ in patients with focal injury. In patients with brain injury, one of the problems that occurs is diffuse axonal injury (DAI). DAI, brain contusions and lacerations will produce a direct clinical effect that leads to coma and death. It is reported that about 26,000 patients die per year due to Diffuse axonal injury (DAI) and 20,000-45,000 patients suffer from physical and mental decline (Reilly 1997, Schouten \& 
Maas 2007). Diffuse Brain Injury can exist in four principal forms: 1. Diffuse axonal injury (DAI), 2. Diffuse hypoxic/anoxic/ischemic injury, 3. Diffuse swelling, and 4. Diffuse vascular injury. Of these four forms, DAI is the one that is gaining the most attention particularly because of its less severe form to sequalae of subtle brain injury. Traumatic DAI is also called shearing injury, diffuse white matter shearing injury and inner cerebral trauma (Ramamurthi \& Tandons 2014).

Estimating the outcomes of head injuries and determining the best prognostic indicators are still interesting and continuing issues for clinicians and statisticians in the world. Prediction of outcomes of head injury patients is the basis for better therapeutic strategies. To assess patients' progressiveness has importance in counseling the patients' family. Commonly used outcome measuring instruments in brain injury patients are Glasgow Outcome Score (GOS), the Extended GOS, Disability Rating Scale (DRS) and Barthel scale (Wilson et al 1998, Jennett et al 1981). GOS, which has been widely accepted as a standard measure for describing outcomes in brain injury, has a narrow validity and variability among observers. The outcome of brain injury patients is a dynamic and time-dependent process. Although longer follow-up period assumes more data, this is comparable to the fact that the high number of patients lost from follow-up (Narayan et al 1996, Reilly 1997, Jennett B 2005).

Barthel Index is an ordinal scale used to measure a person's ability to perform daily activities. Barthel Index consists of 10 items that measure the daily function of a person, especially the activities of daily living and mobility. The items include eating, moving from wheelchair to bed and returning, treatment, transferring to and from baths, toilets, walking on a flat surface, going up and down stairs, dressing, and bowel and bladder continence (Mahoney \& Barthel 1965, Nakao et al 2010)

Neuroprotective therapy in brain injury has been the subject of many clinical, laboratory, and animal experimental studies (Ying 2008). The developing one is neuroprotective types of neuropeptides, including adrenocorticotropin analogues (ACTH). There is controversy in neuroprotective administration to patients with brain injury. We considered this as a novel problem with limited literatures, so this issue was worth examining. Until now there has been no research on clinical outcome either according to GOS and Barthel Index from DAI after adrenocorticotropin and without adrenocorticotropin analogues in Dr. Soetomo Hospital (Vink \& Van Den Heuvel 2004, Ivanova \& Levitskaya 2007, Storozhevykh et al 2007, Timoshenko et al 2008). The aim of this study was to analyze the effect of ACTH analogue on the clinical output (GOS and Barthel Index) in patients with Diffuse Axonal Injury at hospital discharge, 3 months and 6 months post-treatment.

\section{MATERIALS AND METHODS}

This was a prospective analytic observational study that presented DAI cases receiving treatment from June 1, 2013 to June 30, 2014. Inclusion criteria: Adult age (1864 years, WHO 2010), not monitored by ICP, and willing to participate in the study by signing the informed consent.

Exclusion criteria: significant injuries outside the neurosurgery section, undergoing surgery, disturbances of airway, breathing and circulation system, and bloody rinorrhea. Patients suffering from Diffuse Axonal Injury who went to the health service of Dr. Soetomo Hospital underwent physical examination and non-contrast head CT scans, then CIE was done to the patients or families of the patients regarding the condition of the disease and its treatment. Then, the patients received request to be willing to follow the study. GCS (Glasgow Coma Scale) at the onset of admission was recorded. During hospitalization, the patients received either ACTH analogue therapy or not, depending on the treating physician. After discharge from the hospital, patients' data collection was performed at discharge, and 3 and 6 months after the discharge for GOS (Glasgow Outcome Scale) assessment, ie the method to assess the outcome of brain injury patients expressed in scores 1, 2, 3, 4 and 5 , and the Barthel Index (ordinal scale to measure a person's ability to perform daily activities). At the end of the period, data analysis was done with SPSS version 20.0 .

\section{RESULTS}

In this study, total samples meeting the inclusion criteria were 90 patients. A total of 17 patients died, 28 patients refused to participate in the study, and 7 patients did not visit the neurosurgical clinic (loss of follow up). These patients were categorized as drop-outs with a total of 52 patients, so that the samples whose data could be processed were as many as 38 patients.

Characteristics of the sample can be seen in Table 1 where the proportion of males versus females is 3.2: 1 . The samples studied were mostly categorized as severe brain injury $(n=21,55.3 \%)$, with the classification of Diffuse Axonal Injury grade I as dominant category $(n=9 ; 50 \%)$. 
Table 1. Characteristics of research subjects

\begin{tabular}{llcc}
\hline \multicolumn{2}{c}{ Characteristics } & N & Percentage (\%) \\
\hline Sex & Male & 29 & 76.3 \\
& Female & 9 & 23.7 \\
\hline Age & Mean $( \pm$ SD) & \multicolumn{2}{c}{$30.94(11.82)$} \\
\hline $\begin{array}{l}\text { Brain injury } \\
\text { category }\end{array}$ & SBI & 21 & 55.3 \\
& & & \\
\hline DAI category & MBI & 17 & 44.7 \\
& Grade I & 19 & 50 \\
& Grade II & 6 & 15.8 \\
\hline Treatment & Grade III & 13 & 34.2 \\
& Control & 26 & 68.4 \\
& ACTH & 12 & 31.6 \\
& analogue & & \\
\hline
\end{tabular}

Mean GCS at admission was 8.13, while GCS at the time of discharge was 11.3. The GCS difference at discharge in these two groups was not statistically significant $(\mathrm{p}=0.609)$.

Table 2. Characteristics and comparison of GCS in both treatment groups

\begin{tabular}{llccc}
\hline \multicolumn{2}{c}{ Variables } & Median & $\begin{array}{c}\text { Interquartile } \\
\text { Deviation }\end{array}$ & $\mathrm{P}$ \\
\hline $\begin{array}{l}\text { GCS } \\
\text { admission }\end{array}$ & & 8.13 & 0.935 & \\
& Control & 8.5 & 1.25 & 0.359 \\
& ACTH & 8.0 & 1.5 & \\
& analogue & & & \\
\hline GCS & & 11.37 & 1.42 & \\
discharge & & & & \\
& Control & 11.0 & 2.0 & \\
& ACTH & 11.5 & 1.75 & \\
& analogue & & & \\
\hline
\end{tabular}

Glasgow Outcome Scale (GOS) was assessed at discharge from hospital, in three and six months of followup. Fig. 1 shows the course of GOS from the first month to the sixth month.

Fig. 1 shows the GOS at each observation time in each group. The figure shows that GOS scores at the time of discharge in ACTH analogue group is higher than that in control group. In the third and sixth months GOS in both groups achieved the same value.

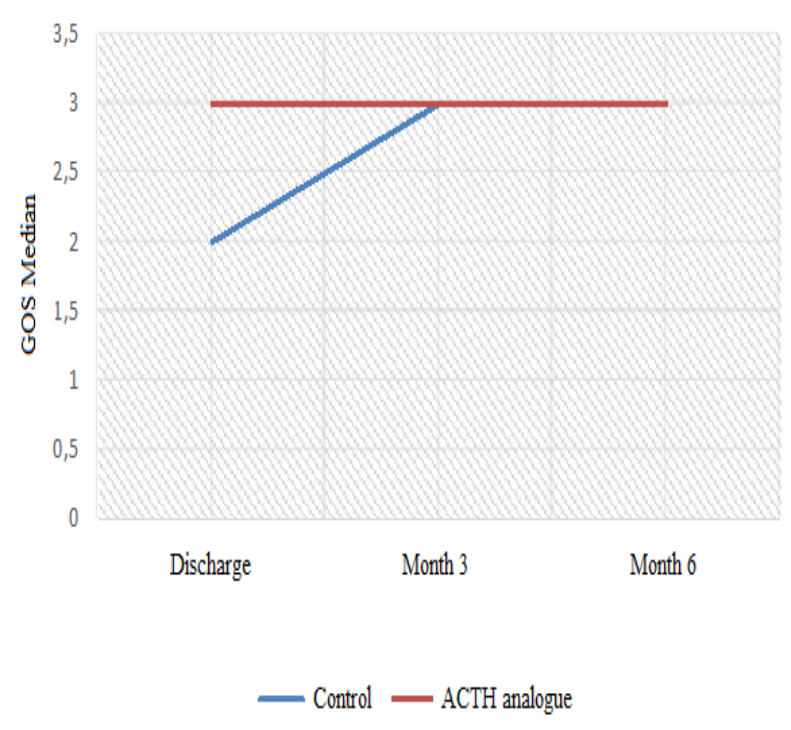

Fig. 1. GOS in both groups.

Comparison of GOS at discharge in the third and sixth months (Table 3) showed higher increasing trend in ACTH analogue group. In the third month, ACTH analogue group had a GOS (3.0) scores compared to the control group (3.0). However, the difference between the two was not statistically significant $(\mathrm{p}=0.218)$. In the sixth month GOS of ACTH analogue group (3.0), compared with that of control group (3.0), showed no significant difference $(\mathrm{p}=0.865)$.

From each observation time, GOS scores were analyzed again to see the level of significance. The analysis results are shown in Table 4 . In control group, differences in GOS scores at discharge, in the third and sixth months had significant difference $(p<0.05)$. In ACTH analogue group, the difference in GOS scores was significant in comparison between hospital discharge and the third month. GOS scores in third and sixth months had no significant difference.

The Barthel Index (BI), as well as GOS, was also assessed at the time of discharge, in the third and sixth months. Figure 2 shows the course of BI scores according to observation time in each treatment group.

Table 3. Comparison of Glasgow Outcome Scale in both treatment groups

\begin{tabular}{lccc}
\hline & \multicolumn{3}{c}{ Glasgow Outcome Scale (Median \pm Interquartile Deviation) } \\
\cline { 2 - 4 } & Hospital discharge & Month 3 & Month 6 \\
\hline Control & $2.0( \pm 1.0)$ & $3.0( \pm 1.0)$ & $3.0( \pm 1.0)$ \\
ACTH analogue & $3.0( \pm 1.0)$ & $3.0( \pm 0.75)$ & $3.0( \pm 1.0)$ \\
P value & 0.447 & 0.218 & 0.865 \\
\hline
\end{tabular}


Table 4. Comparison of GOS median of each observation time in each group

\begin{tabular}{lcc}
\hline \multicolumn{1}{c}{ GOS } & \multicolumn{2}{c}{ Groups } \\
\cline { 2 - 3 } & Control & ACTH analogue \\
\hline Hospital discharge & $2.0( \pm 1.0) \mathrm{a}$ & $3.0( \pm 1.0) \mathrm{a}$ \\
Month 3 & $3.0( \pm 1.0) \mathrm{b}$ & $3.0( \pm 0.75) \mathrm{b}$ \\
Month 6 & $3.0( \pm 1.0) \mathrm{c}$ & $3.0( \pm 1.0) \mathrm{bc}$ \\
P (Anova Friedman) & 0.000 & 0.001 \\
\hline Different superscripts indicate significant results $(\mathrm{p}<0.05)$ with Wilcoxon Signed Rank Test
\end{tabular}

Table 5. Comparison of BI scores in both groups

\begin{tabular}{lccc}
\hline & \multicolumn{3}{c}{ Barthel Index (Median \pm Interquartile Deviation) } \\
\cline { 2 - 4 } & Hospital discharge & Month 3 & Month 6 \\
\hline Control & $20.00( \pm 13.0)$ & $30.0 \pm \pm 16.0)$ & $40.0( \pm 25.0)$ \\
ACTH analogue & $22.5( \pm 19.0)$ & $40.0 \pm( \pm 21.0)$ & $45.0( \pm 28.0)$ \\
P value & 0.314 & $0.046^{*}$ & 0.289 \\
\hline *Significant $\mathrm{p}<0.05$ & \multicolumn{3}{c}{}
\end{tabular}

*Significant, $\mathrm{p}<0.05$

Table 6. Comparison of mean BI of each observation time in each group

\begin{tabular}{lcc}
\hline \multirow{2}{*}{ Barthel Index } & \multicolumn{2}{c}{ Groups } \\
\cline { 2 - 3 } & Control & ACTH analogue \\
\hline Hospital discharge & $20.00( \pm 13.0)^{\mathrm{a}}$ & $22.5( \pm 19.0)^{\mathrm{a}}$ \\
Month 3 & $30.0( \pm 16.0)^{\mathrm{b}}$ & $40.0( \pm 21.0)^{\mathrm{b}}$ \\
Month 6 & $40.0( \pm 25.0)^{\mathrm{c}}$ & $45.0( \pm 28.0)^{\mathrm{bc}}$ \\
\hline Different supercripts indicate significant results $(\mathrm{p}<0.05)$ with Wilcoxon Signed Rank Test
\end{tabular}

Different superscripts indicate significant results $(\mathrm{p}<0.05)$ with Wilcoxon Signed Rank Test

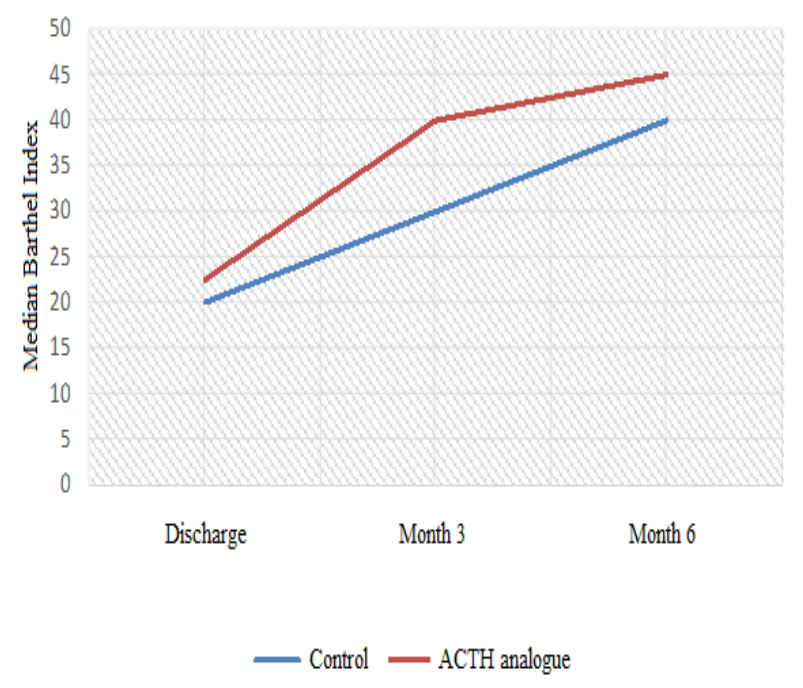

Fig. 3. Barthel Index in both treatment groups at each observation time

Fig. 3 shows median Barthel Index scores at each observation time in each group. Barthel Index of ACTH analogue group was higher than that in control group, as well as in the third and sixth months. The increase in Barthel Index score from the hospital discharge to the third month was also higher in ACTH analogue group compared to that in control group. Data analysis was then continued using a non-parametric Mann-Whitney
$\mathrm{U}$ test. Barthel Index values observed at hospital discharge, in third and sixth month (Table 5) showed that in both groups the values equally had increasing trend. The BI score was higher in ACTH analogue group at all observation times. The increasing trend in Barthel Index from observation time in each group was analyzed to see if the BI value increase was significant (Table 6).

In control group, differences in Barthel Index scores at hospital discharge, in the third and sixth months had significant values $(\mathrm{p}<0.05)$. In ACTH analogue group, the difference in GOS scores was significant in comparison to that at hospital discharge and in the third month. Comparison of GOS scores in third and sixth month showed no significant differences.

\section{DISCUSSION}

This study found that the patients were predominantly males with a ratio of 3.2:1. This is consistent with the prevalence of brain injury in which males are more likely to suffer brain injury than females. In this study, patients were clinically classified as having moderate brain injury (MBI) and severe brain injury (SBI) (55.3\%), while Diffuse Axonal Injury (DAI) classification was mostly classified as DAI grade I in 19 samples (50\%), followed by DAI grade III $(13 ; 34.2 \%)$ 
and lastly the DAI grade II $(6 ; 15.8 \%)$. In this study, DAI grade I was most commonly found, but in the classification of brain injury, the most common was SBI. The severity of brain injury is not always proportional to the severity of the radiological profile. Patients with SBI may present with mild CT Scan radiographs (DAI grade I). This is due to axonal damage profile, which may cause severe brain injury undetectable on CT scan modality.

This study compared the GOS scores in both groups at each observation time. Observation at discharge showed that GOS in ACTH analogue group was 2.58. This score is higher than GOS in control group (2.42). However, this difference is not statistically significant. This may be the case, since ACTH analogue administration has provided improved clinical outcomes as measured by GOS, but has not been clinically significant enough when compared with the control group.

In the third month of observation, GOS score in the group receiving ACTH analogue also had a higher value of 3.08, compared with the control group (2.76). The comparison in the third month also showed no significant difference. In the sixth month, the difference in GOS between ACTH analogue group and control group was also not significant, although the value was higher. It can be assumed that ACTH analogue may have an effect on outcome improvement, but the sample presented is not representative. Observation times of up to 6 months may also be prolonged, so long-term effects of ACTH analogue can be observed. The literatures mentioned that the ACTH analogue had a neuroprotective function with various mechanisms, among others by inhibiting the formation of toxic substances nitric oxyde (NO) and lipid peroxidation (Ashmarin et al 1995, Cherkasova \& Lyapina 2001, Bashkatova et al 2009). The therapeutic duration of ACTH analogue should have been achieved at 20 hours with a combination of intranasal and microcirculation route. In this study, therapeutic effects assessed through GOS outcome have not been able to infer the significance of ACTH analogue used in patients with DAI. However, the trend of clinical improvement has been demonstrated by differences with the control group. Increasing GOS scores from hospital discharge to the third month and from hospital discharge until the sixth month also indicates the effect of ACTH analogue as a neuroprotector and serves to improve the clinical outcome of brain injury in patients with DAI, a result that was the same with the previous study (Dolotov et al 2006, Dmitrieva et al 2009, Marmarou \& Beaumont 2011)

Like the GOS, the Barthel Index (BI) in this study was also compared at each observation time, ie at hospital discharge and after the third and sixth months. At hospital discharge, the BI score in the ACTH analogue group was higher than that in control group, but it was not yet able to produce significant results. Significant results were obtained in the BI comparison in third month observations where that in ACTH analogue group was higher (42.05) than that in control group. Whereas, in sixth month observations, the BI scores were not significant. Even in ACTH analogue group, it was higher than that in control group.

ACTH analogue administration, as expressed in the study of Van de Kar et al (2001) and Dmitrieva et al (2009), has a therapeutic effect at $20 \mathrm{~h}$ after administration. In this study, observation at hospital discharge have shown improvement in clinical outcomes as assessed by BI, in which that in ACTH analogue group was higher than control. In the third month, the effect of ACTH analogue started to appear when the BI score was significantly higher. In this study, ACTH analogue gave better Barthel Index clinical outcomes than control during the observation of the third month. Whereas, in observations in each group, ACTH analogue group showed that the BI score increased significantly from hospital discharge up to the third and sixth months.

Although there were significant results in the clinical outcome variables of the Barthel Index and on the observations of each group, there were still some results that did not fit the literature. This study had several limitations in terms of sampling, observation time and observation variables. The samples taken were patients included in the inclusion criteria by total sampling method. Patients who were followed were those willing to receive ACTH analogue therapy. This was a limitation because ACTH analogue prices in Indonesia were relatively expensive, so in this study only 12 patients were included in the ACTH analogue group.

The observation time of GOS and Barthel Index in this study was at hospital discharge, and after third and sixth month. This was based on the concepts and guidelines of GOS and BI examination, which was assessed at hospital discharge and after the third and sixth month. To obtain more findings during the course of the patients' clinical outcomes, modification of the observation time is necessary, for example, every one month to one year. The observed variables were clinical outcome of Glasgow Outcome Scale (GOS) and Barthel Index (BI). Subjectively, other variables need be observed either to determine the outcome, for example by using cognitive examination or motor examination. Objectively, some biomarkers can also be examined serially.

\section{CONCLUSION}

ACTH analogue administration resulted in higher Glasgow Outcome Scale and Barthel Index scores than that 
in control. Barthel Index scores in the third month observation were significantly different from those in ACTH analogue and control groups. GOS and Barthel Index scores showed clinical improvements at hospital discharge, and in the third and sixth months in group receiving ACTH analogue.

\section{REFERENCES}

Ashmarin IP, Nezavibat'ko VN, Levitskaya NG, Koshelev VB, Kamensky AA (1995) Design and investigation of $\mathrm{ACTH}(4-10)$ analog deprived of Daminoacids and hydrophobic radicals. Neurosci Res Commun 16, 105-112

Bashkatova V, et al (2009). Attenuation by a novel synthetic analogue of ACTH4-7 of the learning and memory deficits in juvenile rats treated with amphetamine in utero: role of nitric oxide. BMC Pharmacol 9, 1

Cherkasova KA, Lyapina LA (2001). Comparative study of modulatory effect of semax and primary proline-containing peptides on hemostatic reactions. Bulletin of Experimental Biology and Medicine 1, 625-626

Dmitrieva V, et al (2010). Semax and pro-gly-pro activate the transcription of neurotrophins and their receptor genes after cerebral ischemia. Cell Mol Neurobiol 30, 71-79

Dolotov OV, et al (2006). Semax, an analog of ACTH(4-10) with cognitive effects, regulates BDNF and trkB expression in the rat hippocampus. Brain Research 1117, 54-60

Ivanova DM, Levitskaya NG (2007). Comparative study of analgesic potency of ACTH4-10 fragment and its analog semax. Bulletin of Experimental Biology and Medicine 143, 5-8

Jallo J, Lotus CM (2009). Neurotrauma and critical care of the brain. New York, Thieme Medical Publishers Inc.

Jennett B (2005). Development of glasgow coma and outcome scales. Journal of Neuroscience 2, 24-28

Jennett B, Snoek J, Bond MR, Brooks N (1981). Disability after severe head injury: observation on the use of the glasgow outcome scale. J Neurol, Neurosurg 44, 285-293

Van de Kar LD, Javed A, Zhang Y, Serres F, Raap DK, Gray TS (2001). 5-HT2A receptors stimulate ACTH, corticosterone, oxytocin, renin, and prolactin release and activate hypothalamic CRF and oxytocin- expressing cells. The Journal of Neuroscience 21, 3572-3579

Mahoney FI, Barthel DW (1965). Functional evaluation: The Barthel Index. Md State Med J 14, 1-4

Marmarou, A, Beaumont, A (2011). Physiology of cerebrospinal fluid and inracranial pressure. In Winn HR (eds.), Youmans Neurological Surgery, 6th ed. United States, Elsevier Saunders, 169

Narayan RK, Wilberger James E, Povlishock JT (1996). The Neurotrauma. New York, McGraw-Hill Companies, 779-829

Nakao S, et al (2010). Relationship between Barthel Index Scores during the acute phase or rehabilitation and subsequent ADL in stroke patients. The Journal of Medical Investigation 57, 81-8

Ramamurthi, Tandons (2014). Manual of neurosurgery. Mumbai, Jaypee brothers medical publishers LTD, 224-228

Reilly P (1997). Head Injury. London, Chapman \& Hall 2-6 Boundary Row, p 40-49. '

Schouten JW, Maas AIR (2007). Epidemiology of traumatic brain injury. In Winn HR (eds.), Youmans Neurological Surgery, 6th ed. United States, Elsevier Saunders, p 3270-3275

Storozhevykh TP, Tukhbatova GR, Senilova YAE, Pinelis VG, Andreeva LA, Myasoyedov NF (2007). Effects of semax and its pro-gly-pro fragment on calcium homeostasis of neurons and their survival under conditions of glutamate toxicity. Bulletin of Experimental Biology and Medicine 143, p 601-604

Timoshenko TV, Poletaeva II, Pavlova GV, Revishchin AV (2008). Effect of neonatal injections of the neuropeptide semax on cell proliferation in hippocampal dentate area in rats of two genotypes. Doklady Biological Sciences 424, 78-80

Vink R, Van Den Heuvel C (2004). Recent advances in the development of multifactorial therapies for the treatment of traumatic brain injury. Expert Opin. Investig. Drugs 13, 1263-1274

Wahyuhadi J, Suryaningtyas W, Indarto R, Faris M, Apriawan T (2014). Pedoman tatalaksanan cedera otak (guideline in management of traumatic brain injury). Surabaya, RSU Dr. Soetomo, Faculty of Medicine, Universitas Airlangga

Wilson JT, Pettigrew LE, Teasdale GM (1998). Structured interviews for the glasgow outcome scale and the extended glasgow outcome scale: Guidelines for their use. J Neurotrauma 15, 573-585

Ying W (2008). The nose may help the brain: intranasal drug delivery for treating neurological diseases. Future neurol 3, 1-4 